\title{
Horizontal ridging with mulching as the best tillage practice to reduce surface runoff and erosion in a Mollisol hillslope at the maize seedling stage
}

\author{
Yucheng Wang ${ }^{1}$, Dayong Guo ${ }^{2}$, Wuliang $\mathrm{Shi}^{1}$, Bin $\mathrm{Li}^{1}$, Jinhu Cui ${ }^{1}$, Ning $\mathrm{Cao}^{1}$, and Yubin \\ Zhang ${ }^{1}$ \\ ${ }^{1}$ Jilin University \\ ${ }^{2}$ Henan University of Science and Technology
}

May 22, 2021

\begin{abstract}
Soil erosion features and ideal tillage practices are not very clear at the crop seedling stage in Chinese Mollisols. Simulated rainfall experiments were conducted at the rainfall intensities of 50 and $100 \mathrm{~mm} \mathrm{~h}-1$ to investigate the differences in soil erosion of a $5^{\circ}$ hillslope during the maize seedling stage between conservation and conventional tillage measures, including cornstalk mulching $(\mathrm{Cm})$, horizontal ridging $(\mathrm{Hr})$, horizontal ridging + mulching $(\mathrm{Hr}+\mathrm{Cm})$, vertical ridging + mulching $(\mathrm{Vr}+\mathrm{Cm})$, flattillage $(\mathrm{CK})$, and vertical ridging $(\mathrm{Vr})$. The results demonstrated that crops could remit soil erosion at the seedling stage by reducing the kinetic energy and changing the distribution of raindrops. The conservation tillage measures significantly alleviated total runoff $(11.7 \%-100 \%)$ and sediment yield $(71.1 \%-100 \%)$, postponed runoff-yielding time ( 85 s-26.1 min), decreased runoff velocity $(71.5 \%-96.7 \%)$, and reduced runoff and soil loss rate, compared to the conventional tillage measures. Practices with mulching showed better performance than Hr. Mulching reduced sediment concentration by decreasing runoff velocity and soil particle filtration in a manner similar to buffer strips. The contour ridge ruptured earlier at $100 \mathrm{~mm} \mathrm{h-1} \mathrm{than} \mathrm{at} 50 \mathrm{~mm}$ h- 1 and changed the characteristics of the soil erosion by providing a larger sediment source to the surface flow. Runoff strength, rather than soil erodibility, was the key factor affecting soil erosion. Decreasing runoff velocity was more important than controlling runoff amount. The $\mathrm{Hr}+\mathrm{Cm}$ treatment exhibited the lowest soil erosion and is, thus, recommended at the corn seedling stage.
\end{abstract}

Horizontal ridging with mulching as the best tillage practice to reduce surface runoff and erosion in a Mollisol hillslope at the maize seedling stage

Running title: Horizontal ridge with mulching reduces surface runoff and erosion

Yucheng Wang ${ }^{1,+}$, Dayong Guo ${ }^{2,+}$, Wuliang $\mathrm{Shi}^{1}$, Bin $\mathrm{Li}^{1}$, Jinhu $\mathrm{Cui}^{1}$, Ning $\mathrm{Cao}^{1,}{ }^{*}$, and Yubin Zhang ${ }^{1, *}$

${ }^{1}$ College of Plant Science, Jilin University, Changchun, China

${ }^{2}$ Agricultural College, Henan University of Science and Technology, Luoyang, China

+ , contribution equally to this work

*, Correspondence

Ning Cao and Yubin Zhang, College of Plant Science, Jilin University, Changchun 130062, China.

E-mail: cao_ning@jlu.edu.cn; ybzhang@jlu.edu.cn

ORCID

Yu-bin Zhang https://orcid.org/0000-0003-4920-3100 


\section{ABSTRACT}

Soil erosion features and ideal tillage practices are not very clear at the crop seedling stage in Chinese Mollisols. Simulated rainfall experiments were conducted at the rainfall intensities of 50 and $100 \mathrm{~mm} \mathrm{~h}^{-1}$ to investigate the differences in soil erosion of a $5^{\circ}$ hillslope during the maize seedling stage between conservation and conventional tillage measures, including cornstalk mulching $(\mathrm{Cm})$, horizontal ridging $(\mathrm{Hr})$, horizontal ridging + mulching $(\mathrm{Hr}+\mathrm{Cm})$, vertical ridging + mulching $(\mathrm{Vr}+\mathrm{Cm})$, flat-tillage $(\mathrm{CK})$, and vertical ridging (Vr). The results demonstrated that crops could remit soil erosion at the seedling stage by reducing the kinetic energy and changing the distribution of raindrops. The conservation tillage measures significantly alleviated total runoff $(11.7 \%-100 \%)$ and sediment yield $(71.1 \%-100 \%)$, postponed runoff-yielding time $(85$ s-26.1 min), decreased runoff velocity (71.5\%-96.7\%), and reduced runoff and soil loss rate, compared to the conventional tillage measures. Practices with mulching showed better performance than Hr. Mulching reduced sediment concentration by decreasing runoff velocity and soil particle filtration in a manner similar to buffer strips. The contour ridge ruptured earlier at $100 \mathrm{~mm} \mathrm{~h}^{-1}$ than at $50 \mathrm{~mm} \mathrm{~h}^{-1}$ and changed the characteristics of the soil erosion by providing a larger sediment source to the surface flow. Runoff strength, rather than soil erodibility, was the key factor affecting soil erosion. Decreasing runoff velocity was more important than controlling runoff amount. The $\mathrm{Hr}+\mathrm{Cm}$ treatment exhibited the lowest soil erosion and is, thus, recommended at the corn seedling stage.

\section{KEYWORDS}

soil erosion, conservation tillage, Chinese Mollisols, maize seedling stage, rainfall simulation, rainfall intensity

\section{Introduction}

Maize (Zea mays L.) is often cultivated on slopes in the Mollisols of Northeast China (You et al., 2021) for natural fertile mollic epipedon and high productivity (Zhang et al., 2012; Zhao et al., 2015). However, sloping farmlands, which are considered as the main site of soil erosion worldwide (Nearing et al., 1997; Ouimet et al., 2009; Römkens et al., 2002), occupy $57.7 \%$ of the arable land in this region (Chinese Ministry of Water Resources et al., 2010). Unfortunately, soil erosion is a natural process, but it has been vastly and needlessly accelerated by unsustainable agriculture practices globally, incurring an annual cost of $\$ 8$ billion to global GDP and reducing global agri-food production by 33.7 million tons and water by 48 billion $\mathrm{m}^{3}$ (Sartori et al., 2019). With the removal of fertile surface by intensive tillage, soil erosion directly induces soil layer thinning, quality degradation, and crop yield decline (DeLonge \& Stillerman, 2020; Liu et al., 2013; Montgomery, 2007, 2017; Thaler et al., 2021; Yang et al., 2016).

Conservation tillage is a widely used key agronomic measure to rebuild healthy soil worldwide (Bombino et al., 2019; Busari et al., 2015; Derpsch et al., 2014; Kader et al., 2017; Lal, 2018). It has long been considered a feasible and effective approach to control soil erosion (Bombino et al., 2021; Liu et al., 2011; Palm et al., 2014; Prosdocimi et al., 2016b; Tran \& Kurkalova, 2019) and to restrict agricultural non-point source pollution (Bailey et al., 2013). Compared with conventional tillage, it has positive effects on soil physical characteristics (Blanco-Moure et al., 2012; Kumar et al., 2012; Sharratt et al., 2012), soil fertility (Polyakov \& Lal, 2008; Van den Putte et al., 2012), and agricultural productivity (Hansen et al., 2012; Hobbs et al., 2008).

Previous studies have clearly demonstrated the significantly positive effects of vegetation on soil erosion (Huang et al., 2014; Keesstra, 2007; Keesstra et al., 2016). However, currently, few studies have considered the active influences of crops on soil erosion, especially at the seedling stage (Cerdà et al., 2017; Keesstra et al., 2016; Prosdocimi et al., 2016b; Wang et al., 2018). Though some reports provided better understanding and essential evidence of the effect of conservation tillage on effectively controlling soil erosion by simulated rainfall in the region, they focused on bare slope lands (An et al., 2012; Li et al., 2016; Liu et al., 2011; Lu et al., 2016; Song \& Zhang, 2011; Xu et al., 2018). The status of soil erosion at the crop seedling stage under different tillage practices have been rarely reported (Ma et al., 2013). Several reasons explain the vulnerability of a slope farmland to soil erosion at the crop seedling stage: (i) a seedling crop has extremely low land-coverage rate and limited soil-solid capability because of its small canopy and root system (Figure 
1), different from natural vegetation cover types (Wang et al., 2018; Zhang et al., 2009); (ii) rainfall erosivity would be further enhanced in the mid-21st century (Zhang et al., 2010); and (iii) concentrated precipitation during the crop seedling stage betided frequently in the region (Sun et al., 2000). Hence, alleviating soil erosion in the region, especially during the crop seedling stage, is important for soil loss reduction, aquatic environment improvement, and agricultural sustainable development.

In line with the above-mentioned findings, our study evaluated the effects of four conservation and two conventional tillage practices on soil erosion under simulated rainfall conditions at the maize seedling stage on a black soil sloping farmland in Northeast China. Our study provides insights to determine suitable tillage measures to control soil erosion at the corn seedling stage in the studied region and a reference for further studies on alleviating erosion pressure in other regions.

\section{Materials and Methods}

\section{Simulated rainfall setup}

The experiments were conducted at the artificial rainfall simulation plots in the Science and Technology Park of Soil and Water Conservation, Institute of Soil and Water Conservation of Heilongjiang Province, Binxian County, located in the central region of the Mollisols region of Northeast China. A down-sprinkler rainfall simulator was used to apply rainfall; the system has three different nozzle sizes, which can be adjusted to rainfall intensities ranging from 30 to $200 \mathrm{~mm} \mathrm{~h}^{-1}$ (Shen et al., 2005). A removable waterproof canvas ceiling was used on top of the system to protect all experimental plots from natural rainfall, and a set of droppable canvases were used to surround the testing plots to eliminate wind impacts during the experiment (Figure 2 and 3$)$.

\section{Preparation of experimental plots}

In this study, we used 10-m long and 1-m wide plots. The slope gradient of the plots was set to $5^{\circ}$ to simulate the typical natural geomorphological conditions of the gently sloping farmland in the region (Zhao, 1986). The depth of the tested black soil was $0.3 \mathrm{~m}$, similar to the average thickness of the A-horizon of black soil (Xu et al., 2010). The black soil layer was followed by a $0.3-\mathrm{m}$ sand layer.

The soil used in this study was typical black soil with $22.01 \mathrm{~g} \mathrm{~kg}^{-1}$ of organic matter. It was collected from the top-30 cm soil layer in a local slope farmland. The agglomerate impurities were removed manually, but without passing the soil through a sieve, to maintain its natural state. The soil was packed into plots on the sand layer for a period of 1.5 years to ensure that the bulk density $\left(1.20 \mathrm{~g} \mathrm{~cm}^{-3}\right)$ reached the field level by natural deposition and the soil structure recovered to the natural cropland state before the experiment.

We used Xianyu 335 (DuPont Pioneer Ltd., USA), a widely cultivated maize variety in Northeast China. Seeds were sown at a distance of $0.4 \mathrm{~m}$ between rows and $0.2 \mathrm{~m}$ between plants distance and fertilized with urea $\left(\mathrm{CO}_{2}\left(\mathrm{NH}_{2}\right)_{2}\right)$ at $150 \mathrm{~kg} \mathrm{ha}^{-1}$ in early June in 2013 . All plots were plowed simultaneously at $\sim 0.2 \mathrm{~m}$ depth. Ridges were stacked in all ridging plots one month after sowing, obeying the local routine in the region. Air seasoning maize stalks were chopped into approximately 5 -cm fragments and mulched onto mulching plots at a dosage of $20000 \mathrm{~kg} \mathrm{ha}^{-1}$.

\section{Experimental design and procedures}

Two tillage systems, conventional and conservation, were applied in this study. The two conventional tillage practices included flat-planting without ridges and mulching (control, CK) and vertical ridging without mulching (Vr). Four conservation tillage measures included flat-planting and mulching without ridges $(\mathrm{Cm})$, horizontal ridging without mulching $(\mathrm{Hr})$, horizontal ridging with mulching $(\mathrm{Hr}+\mathrm{Cm})$, and vertical ridging with mulching $(\mathrm{Vr}+\mathrm{Cm})$. All plots were randomly arranged (Figure 2).

In Northeast China, soil erosion is caused by two types of rainfall events: short-duration rainfall under high-intensity rainstorm and long-duration rainfall under low-intensity rain. In terms of rainstorm status, generally momentary rainfall intensities larger than $23.4 \mathrm{~mm} \mathrm{~h}^{-1}$ cause soil erosion with an approximate 
duration of $1 \mathrm{~h}$ in the region (Zhang et al., 1992). Thus, in this study, two rainfall intensities of 50- and $100-\mathrm{mm} \mathrm{h}^{-1}$ were used as representative rainfall intensities lasting for a period of $1 \mathrm{~h}$.

All plots were subjected to a pre-rain at $30 \mathrm{~mm} \mathrm{~h}^{-1}$ for 5 min to maintain consistent soil moisture, consolidate loose soil particles, and flatten the soil surface before $24 \mathrm{~h}$ of experiments (Shen et al., 2016). Before the experiment, the rainfall intensity was calibrated to ensure the achievement of target intensity and fulfillment of experimental requirements (uniformity $>90 \%$, Figure 3a) (Shen et al., 2016). After each rainfall, the plots were repaired for the next run via a process including drying, replacement and recovery of the topsoil layer and lost cornstalk, smashing of soil clods, restoration of broken ridges, and smoothing of irregularities on the surface (Polyakov \& Nearing, 2003).

\section{Experimental measurements}

\section{Runoff process}

A stopwatch was started immediately after the beginning of rainfall to measure the runoff-yielding time. The runoff velocity was measured thrice for each rainfall intensity in three soil sections $(2,5$, and $7 \mathrm{~m}$ from the top soil) after the runoff became steady, using the $\mathrm{KMnO}_{4}$ dye tracer method (Shen et al., 2016).

\section{Runoff and soil loss}

Runoff and sediment samples were collected in 15-L buckets every 5 min once the runoff occurred during each rainfall event. After allowing sediment settling for $1 \mathrm{~h}$, the volume of supernatant was measured to calculate runoff loss. The sediment samples were oven-dried at 45 and weighed to calculate sediment yield and runoff rate.

\section{Soil splash-erosion}

Standard Morgan field splash cups (Morgan, 1978) were used to measure the amount of soil splash transport. The soil splash detachment, potentially more related to soil erodibility, was measured by using specially designed aluminum cylindrical splash cups with $3 \mathrm{~cm}$ depth, $6 \mathrm{~cm}$ diameter, and a multihole bottom. The undisturbed soil was cut and packed into the cups and weighed immediately after drying at 45 . The soil cups were allowed to absorb moisture at room temperature for $24 \mathrm{~h}$. Three Morgan cups were arranged into each plot on the top-, mid-, and lower-slopes (at a distance of 2, 5, and $7 \mathrm{~m}$ from top, respectively), together with the small cups according to the position shown in Figure 3 (b, c). Rainfall was applied for 15 min to allow splash-erosion to occur. The soil was again weighed immediately after drying, and the splash transport and detachment amounts were measured.

\section{Data analysis}

All data were analyzed for statistical significance of treatment effects by one-way analysis of variance (ANOVA) using the software program PASW Statistics 16.0 (SPSS company, Chicago, IL, USA). The least significant difference (LSD) at $p<0.05$ was used to compare the treatment means. Plots were drawn using the software Origin 9.0 (Origin Lab Corporation, Northampton, Massachusetts, USA).

\section{Results}

\section{Raindrop energy and distribution above/below the canopy of seedling corn}

As shown in Tables 1 and 2, the energy and size distribution of raindrops were significantly different between above and below the canopy of seedling corn. For the two rainfall intensities, the canopy mitigation of raindrop energy was observed more in conservation than conventional tillage measures. The percentage of raindrops with less than $2.5 \mathrm{~mm}$ diameter decreased when the raindrops larger than $2.5 \mathrm{~mm}$ diameter decreased at the rainfall intensity of $50 \mathrm{~mm} \mathrm{~h}^{-1}$, whereas the percentage of raindrops with less than $2.0 \mathrm{~mm}$ diameter decreased when that of raindrops larger than $2.0 \mathrm{~mm}$ diameter increased at the rainfall intensity of $100 \mathrm{~mm} / \mathrm{h}$.

\section{Runoff-yielding time and runoffvelocity}


Table 3 shows that conservation tillage measures could significantly delay the runoff-yielding time and decrease surface flow velocity, compared to CK and Vr, at the maize seedling stage. Compared with CK and $\mathrm{Vr}$, the runoff-yielding times of the $\mathrm{Cm}, \mathrm{Hr}, \mathrm{Hr}+\mathrm{Cm}$, and $\mathrm{Vr}+\mathrm{Cm}$ treatments were significantly postponed; the runoff-yielding time advanced at $100 \mathrm{~mm} \mathrm{~h}^{-1}$ than at $50-\mathrm{mm} \mathrm{h}^{-1}$. The $\mathrm{Hr}+\mathrm{Cm}$ treatment successfully prevented runoff yielding throughout the rainfall event under $50 \mathrm{~mm} \mathrm{~h}^{-1}$, and the averagely prolonged runoffyielding time was approximately $26.1 \mathrm{~min}$, which was 23.8 times longer than that of the CK treatment under $100 \mathrm{~mm} \mathrm{~h}^{-1}$. The average delay time durations for other treatments from long to short were $23.6 \mathrm{~min}$ for $\mathrm{Hr}, 5.6 \mathrm{~min}$ for $\mathrm{Cm}$, and $2.8 \mathrm{~min}$ for $\mathrm{Vr}+\mathrm{Cm}$.

Table 3 also shows that the declining effects on surface flow velocity were more obvious under light than under heavy rainfall intensity conditions. Compared to $\mathrm{CK}$, the $\mathrm{Hr}+\mathrm{Cm}, \mathrm{Cm}, \mathrm{Vr}+\mathrm{Cm}$, and $\mathrm{Hr}$ treatments significantly reduced the surface flow velocity, with a decline of $100 \%$ (no runoff generation), $75.8 \%, 71.9 \%$, and $83.5 \%$, respectively, at the rainfall intensity of $50 \mathrm{~mm} \mathrm{~h}^{-1}$ and $96.4 \%, 82.9 \%, 77.7 \%$, and $71.5 \%$, respectively, at the rainfall intensity of $100 \mathrm{~mm} \mathrm{~h}^{-1}$. However, $\mathrm{Vr}$ significantly increased the runoff velocity by $50.3 \%$ and $10.1 \%$ at the rainfall intensities of 50 and $100 \mathrm{~mm} \mathrm{~h}^{-1}$, respectively.

\section{Total runoff and soil loss}

\section{Surface runoff}

The conservation tillage measures of $\mathrm{Cm}, \mathrm{Hr}$, and $\mathrm{Hr}+\mathrm{Cm}$ significantly reduced the runoff amount compared to CK under the two rainfall intensities at the maize seedling stage (Figure 4). Compared to CK, the Cm and $\mathrm{Hr}$ treatments reduced the runoff amount by $70.46 \%$ and $87.76 \%$, respectively, at $50 \mathrm{~mm} \mathrm{~h}^{-1}$ and by $44.78 \%$ and $58.85 \%$, respectively, at $100 \mathrm{~mm} \mathrm{~h}^{-1}$, respectively. The $\mathrm{Hr}+\mathrm{Cm}$ treatment entirely prevented runoff generation at $50 \mathrm{~mm} \mathrm{~h}^{-1}$ and was still effective at $100 \mathrm{~mm} \mathrm{~h}^{-1}$, restricting the total runoff amount to a very low level of $20.79 \mathrm{~L}$, accounting for only $16.61 \%$ of CK, and even causing ridge rupture. The $\mathrm{Vr}+\mathrm{Cm}$ treatment significantly decreased the runoff amount by $54.61 \%$ compared to CK at $50 \mathrm{~mm} \mathrm{~h}^{-1}$, but there was no difference at $100 \mathrm{~mm} \mathrm{~h}^{-1}$. Conversely, Vr significantly enhanced the runoff amount by $25.04 \%$ compared to $\mathrm{CK}$ at $50 \mathrm{~mm} \mathrm{~h}^{-1}$, but there was no difference at $100 \mathrm{~mm} \mathrm{~h}^{-1}$.

\section{Soil loss}

The total soil loss in $\mathrm{Cm}, \mathrm{Hr}, \mathrm{Vr}+\mathrm{Cm}$, and $\mathrm{Hr}+\mathrm{Cm}$ was significantly lower than $\mathrm{CK}$ at the maize seedling stage (Figure 5). Vr significantly augmented the soil loss amount by $7.03-$ and 2.29 -fold at the rainfall intensities of 50 and $100 \mathrm{~mm} \mathrm{~h}^{-1}$, respectively. However, the total soil loss of CK was greater than that of $\mathrm{Cm}, \mathrm{Hr}$, and $\mathrm{Vr}+\mathrm{Cm}$, exceeding by $11.87-, 5.99-$, and 7.79 -fold at $50 \mathrm{~mm} \mathrm{~h}^{-1}$ and by $11.10-, 4.37-, 16.18-$, and 20.47-fold at $100 \mathrm{~mm} \mathrm{~h}^{-1}$, respectively. Like the effect on runoff amount, $\mathrm{Hr}+\mathrm{Cm}$ also showed the best performance for preventing runoff and soil loss at $50 \mathrm{~mm} \mathrm{~h}^{-1}$ (Table 3 and Figure 4). The total soil loss was not different among the other three conservation measures of $\mathrm{Cm}, \mathrm{Hr}$, and $\mathrm{Vr}+\mathrm{Cm}$ at $50 \mathrm{~mm} \mathrm{~h}^{-1}$, although the ridges of $\mathrm{Hr}$ were breached; meanwhile, $\mathrm{Cm}, \mathrm{Vr}$, and $\mathrm{Hr}+\mathrm{Cm}$ showed no significant difference, but $\mathrm{Hr}$ showed a significantly different soil loss from the three treatments because of ridge rupturing at $100 \mathrm{~mm} \mathrm{~h}^{-1}$. The results indicated that the conservation measures were useful in reducing soil loss; in particular, mulching was more effective than contour ridging, as seen in the case where the soil loss caused by Hr increased more than that caused by other conservation measures, especially under high rainfall intensity conditions, when contour ridges were destroyed.

\section{Horizontal ridge rupture}

As shown in Figures 6 and 7, mulching could not totally prevent contour ridge rupture, especially under heavy rainfall conditions; for example, the ridge of $\mathrm{Hr}$ was destroyed at both rainfall intensities, while that of $\mathrm{Hr}+\mathrm{Cm}$ occurred only at $100 \mathrm{~mm} \mathrm{~h}^{-1}$. The ridge rupture occurred earlier at $100 \mathrm{~mm} \mathrm{~h}^{-1}$ than at $50 \mathrm{~mm}$ $\mathrm{h}^{-1}$. The averaged runoff rate of $\mathrm{Hr}$ was 3.83 -fold greater after ridge rupture than before at $50 \mathrm{~mm} \mathrm{~h}^{-1}$, being 22.63- and 1.55-fold greater under $\mathrm{Hr}$ and $\mathrm{Hr}+\mathrm{Cm}$ at $100 \mathrm{~mm} \mathrm{~h}^{-1}$, respectively. Meanwhile, the average soil loss rate of $\mathrm{Hr}$ was 13.84-fold greater after ridge rupture than before at $50 \mathrm{~mm} \mathrm{~h}^{-1}$, being 94.70 - and 1.14-fold greater under $\mathrm{Hr}$ and $\mathrm{Hr}+\mathrm{Cm}$ at $100 \mathrm{~mm} \mathrm{~h}^{-1}$, respectively. 


\section{Erosion process}

\section{Surface runoff process}

The changing trends of runoff in most treatments were similar at both 50 and $100 \mathrm{~mm} \mathrm{~h}^{-1}$ (Figure 6), including two stages: 1) a low starting rate followed by a dramatic increase during the initial runoff-yielding period, and 2) a relatively stable rate that persisted until the end of rainfall experiment. However, the regular changing trends could be interfered with by a ridge rupture in the $\mathrm{Hr}$ and $\mathrm{Hr}+\mathrm{Cm}$ treatments, with runoff rates suddenly rising in the Hr-treated plot at 40 and 25 min under the rainfall intensities of 50 and $100 \mathrm{~mm}$ $\mathrm{h}^{-1}$, respectively, and in the $\mathrm{Hr}+\mathrm{Cm}$ treatment at $60 \mathrm{~min}$ under $100 \mathrm{~mm} \mathrm{~h}^{-1}$ rainfall. In comparison, the average runoff rate of $\mathrm{CK}$ was greater than that of $\mathrm{Cm}, \mathrm{Vr}, \mathrm{Hr}$, and $\mathrm{Vr}+\mathrm{Cm}$ by 2.9-, 0.8-, 5.0-, and 1.9-fold at $50 \mathrm{~mm} \mathrm{~h}^{-1}$, respectively, and by 1.8-, 1.0-, 1.7-, and 1.2-fold, respectively, at $100 \mathrm{~mm} \mathrm{~h}^{-1}$. In addition, the average runoff rate of $\mathrm{CK}$ was 3.7 -fold greater than that of $\mathrm{Hr}+\mathrm{Cm}$ at $100 \mathrm{~mm} \mathrm{~h}^{-1}$.

Compared to $\mathrm{CK}$, the $\mathrm{Cm}, \mathrm{Hr}$, and $\mathrm{Hr}+\mathrm{Cm}$ treatments reduced the runoff loss rates significantly on all points within the entire rainfall experiment (Figure 6). At $50 \mathrm{~mm} \mathrm{~h}^{-1}$, $\mathrm{Hr}$ showed a better capacity for controlling runoff loss rates than $\mathrm{Cm}$. Vr had no notable effects on runoff loss rates at most of the points at $100 \mathrm{~mm} \mathrm{~h}^{-1}$ but could promote the loss rate significantly at $50 \mathrm{~mm} \mathrm{~h}^{-1}$, including the whole process except for the runoff-yielding point. The runoff loss rates of $\mathrm{Vr}+\mathrm{Cm}$ were significantly lower than those of CK at $50 \mathrm{~mm} \mathrm{~h}^{-1}$, with an average runoff rate of $53.6 \%$, while the reduction was very limited at $100 \mathrm{~mm} \mathrm{~h}^{-1}$.

Figure 6 also illustrates that the stable runoff rates were lower at $50 \mathrm{~mm} \mathrm{~h}^{-1}$ than at $100 \mathrm{~mm} \mathrm{~h}^{-1}$ for all treatments. The runoff rates of $\mathrm{CK}, \mathrm{Cm}, \mathrm{Vr}, \mathrm{Hr}, \mathrm{Vr}+\mathrm{Cm}$, and $\mathrm{Hr}+\mathrm{Cm}$ stabilized at approximately 91.8, $30.1,118.7,20.3,48.2$, and $0 \mathrm{~mL} \mathrm{~s}^{-1}$ at $50 \mathrm{~mm} \mathrm{~h}^{-1}$, respectively, and at 198.6, 117.4, 192.5, 122.9, 176.1, and $49.9 \mathrm{~mL} \mathrm{~s}^{-1}$ at $100 \mathrm{~mm} \mathrm{~h}^{-1}$, respectively.

The results suggested that the mulching treatments, including $\mathrm{Cm}, \mathrm{Hr}+\mathrm{Cm}$, and $\mathrm{Vr}+\mathrm{Cm}$, were able to mitigate rate-changing magnitudes compared to the corresponding tillage measures without mulching, that is $\mathrm{CK}, \mathrm{Hr}$, and $\mathrm{Vr}$, indicating that more rainfall was infiltrated or stored under the treatments with mulching compared to those without mulching.

\section{Sediment yielding process}

As shown in Figure 7, the sediment loss rates in most treatments varied based on the changing trends of the runoff loss rate (Figure 6), with a relatively low starting level and then varied within a certain range based on rainfall intensity. The four conservation practices could effectively reduce soil loss rate compared to the conventional tillage of CK and Vr, except that the ridges ruptured, and the Vr treatment obviously enhanced the soil loss rate compared to CK. In comparison, the average soil loss rates of CK were 10.04-, 3.68-, and 6.59-fold greater than those of $\mathrm{Cm}, \mathrm{Hr}$, and $\mathrm{Vr}+\mathrm{Cm}$ at $50 \mathrm{~mm} \mathrm{~h}^{-1}$, respectively, and 13.03-, 3.03-, 16.18-, and 12.60-fold greater than those of $\mathrm{Cm}, \mathrm{Hr}, \mathrm{Vr}+\mathrm{Cm}$, and $\mathrm{Hr}+\mathrm{Cm}$ at $100 \mathrm{~mm} \mathrm{~h}^{-1}$, respectively. However, the averaged soil loss rates of $\mathrm{Vr}$ were 7.03 - and 2.28-fold greater than those of CK at 50- and 100- $\mathrm{mm} \mathrm{h}^{-1}$, respectively.

As mentioned earlier in the Materials and Methods section, the regular changing trends were interfered by the ridge rupture in the $\mathrm{Hr}$ or $\mathrm{Hr}+\mathrm{Cm}$ treatments. As Figure 5 shows, $\mathrm{Hr}$ could reduce the sediment loss rate throughout the entire rainfall process, averaging $81.95 \%$ and $68.40 \%$ of CK under the two rainfall intensities, but two of the three ridge rupture time points made the instantaneous rates higher than the earlier rates. The impact of ridge rupture was greater at $100 \mathrm{~mm} \mathrm{~h}^{-1}$ than at $50 \mathrm{~mm} \mathrm{~h}^{-1}$, and the subsequent soil loss rates would stay higher thereafter, rather than being at the former level at $100 \mathrm{~mm} \mathrm{~h}^{-1}$, which dropped to former rates under $50 \mathrm{~mm} \mathrm{~h}^{-1}$.

During rainfall events, the mean soil loss rates in the three mulching treatments of $\mathrm{Cm}, \mathrm{Vr}+\mathrm{Cm}$, and $\mathrm{Hr}+\mathrm{Cm}$ were approximately $0.01,0.02$, and $0 \mathrm{~g} \mathrm{~s}^{-1}$ at $50 \mathrm{~mm} \mathrm{~h}^{-1}$, and $0.09,0.07$, and $0.09 \mathrm{~g} \mathrm{~s}^{-1}$ at $100 \mathrm{~mm}$ $\mathrm{h}^{-1}$, respectively, being significantly lower than those of CK, which were approximately 0.15 and $1.18 \mathrm{~g} \mathrm{~s}^{-1}$ at 50 and $100 \mathrm{~mm} \mathrm{~h}^{-1}$, respectively. The soil loss rates of these mulching treatments were also lower than those of the non-mulching treatments, such as $\mathrm{Vr}$ and $\mathrm{Hr}$, which were approximately 1.02 and $0.04 \mathrm{~g} \mathrm{~s}^{-1}$ 
at $50 \mathrm{~mm} \mathrm{~h}^{-1}$ and 2.70 and $0.39 \mathrm{~g} \mathrm{~s}^{-1}$ at $100 \mathrm{~mm} \mathrm{~h}^{-1}$, respectively (Figure 7). In addition, mulching also mitigated the changing trends of sediment loss rate, i.e., restricting the rate variation magnitude to a lower scale. Therefore, the mulching treatments were more effective in controlling the sediment yield compared to the non-mulching treatments.

\section{Factors influencing soil loss}

The relationship between sediment yield and splash-detachment, splash-transport, total runoff, and surface flow rate was analyzed, as shown in Figure 8 and Table 4. The mulching treatments could restrict splasherosion to very low levels, reducing the average splash-detachment and splash-transport amounts from 143.16 to $1.13 \mathrm{~g} \mathrm{~m}^{-2} \mathrm{~h}^{-1}$ and from 1063.90 to $8.93 \mathrm{~g} \mathrm{~m}^{-2} \mathrm{~h}^{-1}$, respectively. The ridge treatments had no significant impacts on splash-erosion. Thus, for uncovered plots, splash erosion was mainly based on rainfall intensity. The linear correlation coefficients $\left(\mathrm{R}^{2}\right)$ of the splash-detachment and splash-transport rates to rainfall intensity were 0.93 and 0.98 , respectively. The splash rates of $\mathrm{Cm}$ were also partly related to the rainfall intensity, but the correlation was more complicated, and thus further study is needed.

In general, the total soil loss increased with the splash-erosion rate, escalating in non-mulching treatments under light rainfall conditions. However, when the plots suffered ridge rupture, the impact of splash-erosion on soil loss appeared to be insignificant. With an increase in runoff volume and velocity, soil loss would also normally ascend, and thus treatments with high runoff volume and velocity would also lead to serious soil loss. However, this regulation was not applicable to mulching treatments.

\section{Discussion}

\section{Effects of tillage measures on runoff}

We verified that crops could act as a type of vegetation cover (Table 1 and 2) and play an important role to mitigate runoff and soil loss on sloping farmlands in agreement with previous studies (Cerda et al., 2017; Keesstra et al., 2016; Prosdocimi et al., 2016a, b; Wang et al., 2018). Different tillage systems had different impacts on soil erosion associated with processes occurring in slope farmlands (Liu et al., 2011; Xu et al., 2018). The Vr treatment has already been verified to increase soil erosion because of microtopography changes (Liu et al., 2011; Zhang et al., 2009). Conservation tillage could significantly postpone runoff yield and slow runoff velocity compared to conventional tillage (Table 3). Our results indicated that horizontal ridges, mulching, or seedling corn canopy were effective in controlling runoff generation (Table 1, 2 and 3), especially at $50 \mathrm{~mm} / \mathrm{h}$, at the maize seedling stage. This might be because the studied conservation measures could enhance the infiltration capacity of water (Table 5) or increase soil surface roughness (RodriguezCaballero et al., 2012; Vermang et al., 2015; Wang et al., 2018), and crop leaves could intercept rainfall and change raindrop diameter and energy (Table 1 and 2) (Ma et al., 2013; Zhang et al., 2015). As there are only limited chances for extreme precipitation in the region (Zhang et al., 2010), adopting Hr and Cm would be able to restrict runoff generation. In addition, these two tillage measures were also efficacious in reducing the runoff-flow velocity, which is a key factor affecting runoff energy and erosiveness (Vermang et al., 2015); both $\mathrm{Hr}$ and $\mathrm{Cm}$ performed better at $50 \mathrm{~mm} \mathrm{~h}^{-1}$ than at $100 \mathrm{~mm} \mathrm{~h}^{-1}$. Our results were in accordance with previous studies on other soil types (Prosdocimi et al., 2016a, b; Xu et al., 2017). The runoff generation was postponed and the surface-flow velocity decreased mainly because both $\mathrm{Hr}$ and $\mathrm{Cm}$ treatments changed the microtopography of the soil with increasing surface roughness (Vermang et al., 2015; Wang et al., 2018) and the infiltration of conservation tillage was higher than that of conventional measures (Table 3 ). The outcome provided more water storage microstructure for the surficial soil, causing the rainwater to infiltrate rather than flowing downhill (Liu et al., 2015; USDA-ARS, 2008, 2013). This outcome also increased the friction between rainwater and land, thereby reducing runoff velocity. Comparing the effects of $\mathrm{Hr}$ and $\mathrm{Cm}, \mathrm{Hr}$ set a higher threshold for runoff yield, as it could lead to more water storage between ridges. However, once the runoff had occurred, Cm performed better, since the presence of cornstalk could reduce the flow velocity to a very low level (Table 1). Thus, $\mathrm{Hr}+\mathrm{Cm}$ is the optimal treatment from the perspective of postponing runoff-yield and restricting the destruction of runoff, once generated.

The runoff loss rate significantly increased following a low start during the runoff generation period and 
then remained stable at a certain level, based on the rainfall intensity. The results correspond to a study on purple soil (Xu et al., 2008). $\mathrm{Hr}$ and $\mathrm{Cm}$ could effectively constrain the runoff loss rates and decrease the runoff amount, especially at $50 \mathrm{~mm} \mathrm{~h}^{-1}$. The $\mathrm{Hr}+\mathrm{Cm}$ treatment, which combined horizontal ridging and mulching, always had an effective influence on runoff under all rainfall types, especially for preventing runoff throughout the experiment under the rainfall intensity of $50 \mathrm{~mm} \mathrm{~h}^{-1}$. As runoff is the main vector affecting both soil loss and agricultural nonpoint source pollution (Hudson, 2015; Zhang et al., 2007), $\mathrm{Hr}+\mathrm{Cm}$ should be recommended as an effective tillage practice in the region.

However, this recommendation would engender extremely higher outliers for runoff rate as a real-time response to ridge rupture when the plots were treated with $\mathrm{Hr}$, especially under heavy rainfall conditions ( $\mathrm{Li}$ et al., 2016; Lu et al., 2016). In this case, the water held by the two adjacent ridges drained immediately after ridge rupture and outrushed into the next inter-ridge area, causing either successive ridge ruptures or runoff overflow, both of which could prompt a sudden upsurge in runoff rate, in accordance with the results of Xu et al. (2018). Consequently, the total runoff loss amount also ascended. The rising magnitude caused by ridge rupture depended on the rupture time and location of the initially ruptured ridge. For instance, in the Hr-treated plot, ridge rupture occurred relatively earlier and closer to the top of the plot under the rainfall intensity of $100 \mathrm{~mm} \mathrm{~h}^{-1}$ than under $50 \mathrm{~mm} \mathrm{~h}^{-1}$ (Figure 6 and 7), thereby resulting in greater runoff loss. Thus, enhancing the quality of ridges to improve their water pressure tolerance capability is vital when applying horizontal ridges (Liu et al., 2014a). It was found that mulching could directly lead to water absorption and protection of a ridge from saturation and erosion by raindrop and runoff (Cerda et al., 2016; Jordan et al., 2010), thereby reducing the risk of ridge rupture. The results confirmed that the Hr-treated plots suffered three times as many ridge ruptures, while the $\mathrm{Hr}+\mathrm{Cm}$ plots suffered only one ridge rupture. Moreover, no successive ridge ruptures were observed in the $\mathrm{Hr}+\mathrm{Cm}$ plots, because mulching and soil blocks would likely be obstructed by the next ridge with the presence of cornstalk, rather than triggering successive ridge ruptures, even if one of the ridges happened to rupture. Moreover, ridge-furrow planting under mulching conditions played an effective role in reducing surface runoff with an increase in soil-water infiltration (Gholami et al., 2013; Kader et al., 2017).

$\mathrm{Vr}$ could increase the runoff loss rate and amount under light rainfall conditions, as shown by Shen et al. (2005) and Zhang et al. (2009) on black soil, and by Xu et al. (2008) on purple farmlands compared to the runoff between contours and downslope ridges. Therefore, vertical ridges should be avoided on slope croplands in the region.

\section{Effects of tillage measures on soil loss}

Both $\mathrm{Hr}$ and $\mathrm{Cm}$ could alleviate soil erosion, mainly by improving the microtopography to increase soil surface roughness (Rodriguez-Caballero et al., 2012; Vermang et al., 2015), and improve soil physico-chemical properties. Moreover, Vr should be circumvented as it augments both soil loss rate and amount (Kader et al., 2017; Mulumba \& Lal, 2008).

When there was no ridge rupture during the rainfall, Hr effectively reduced sediment yield and soil loss rate, as shown in previous studies (Garcia-Orenes et al., 2012). However, after ridge rupture, the impacts on sediment loss were much more severe than on runoff, e.g., the runoff rate was amplified 22.6 times compared to its neighboring point, while the sediment loss rate was amplified 94.7 times after ridge rupture occurred in $\mathrm{Hr}$ under a rainfall intensity of $100 \mathrm{~mm} \mathrm{~h}^{-1}$. This outcome may have occurred because the broken ridges, which were normally big soil blocks, were prone to being directly swept and, thus, lost via runoff (Xu et al., 2018). The residual ridge remaining to be washed continuously by runoff would also increase the sediment concentration in runoff after the ridge rupture, leading to a higher soil loss rate. Soil loss would be further amplified if ridge rupture occurred in the top section of the plot and thus likely triggered successive ruptures.

Our study found that Cm was more reliable than Hr in controlling soil loss (Kader et al., 2017; Prosdocimi et al., 2016b), as it could restrict both the sediment yield and soil loss rate to very low levels (Garcia-Orenes et al., 2012). The reason might be that the flow could accumulate sufficient power to detach and transport particles with mulching (Mannering \& Meyer, 1963; Poesen \& Lavee, 1991). In addition, Cm could postpone 
the soil loss rate that increasingly responded to rainfall intensity enhancement, which is an important effect on soil erosion because rainfall has a short duration but high intensity during the maize seeding stage in Northeastern China (Sun et al., 2000; Zhang et al., 2010). This postponing effect would counteract or even eliminate the instantaneous serious destruction due to torrential rain. Hence, $\mathrm{Hr}+\mathrm{Cm}$ significantly prevented soil loss, especially under light rainfall intensity conditions, and thus, in practice, should be suggested to reduce soil erosion.

\section{Influencing factors}

Soil erosion is related to both runoff strength and soil erodibility (Tang, 2004; Wang et al., 2012; Wang, 1993). Runoff serves as a vector for sediment (Hudson, 2015), and the final sediment yield is based on both runoff strength and soil erodibility (Wang, 1993). Runoff strength can be illustrated by volume and velocity, representing its amount and energy, respectively (Prosdocimi et al., 2016a). Splash-erosion was adopted to evaluate soil erodibility ( $\mathrm{Hu}$ et al., 2016). As shown in Table 2, both $\mathrm{Hr}$ and $\mathrm{Cm}$ could restrict runoff (Garcia-Orenes et al., 2012), and mulching could effectively alleviate splash-erosion (Gholami et al., 2013). These are the fundamental principles for weakening soil erosion. Generally, in our study, the treatments with higher runoff strength also suffered worse soil erosion (Figure 4 and 5). However, grievous splash-erosion, i.e., worse erodibility, did not always correspond to high soil loss (Figure 8; Table 4). Therefore, runoff strength should be a direct influencing factor to predict soil erosion.

Except for the effects introduced by tillage, runoff strength was determined by rainfall intensity (Gholami et al., 2013). Our results indicated higher-strength runoff (Woolhiser \& Goodrich, 1988) and more soil loss (Romkens et al., 2002) with heavier rainfall (Figure 4 and 5), which indicated that the hydrological response of the soil is based on Hortonian flow type (Bombino et al., 2021). For example, in the Vr treatment, the runoff volume, runoff velocity, and sediment yield at $100-\mathrm{mm} \mathrm{h}^{-1}$ were 1.67-, 2.26-, and 2.66-fold greater than those at $50 \mathrm{~mm} \mathrm{~h}^{-1}$, respectively; other treatments also showed similar trends (Table 3; Figure 4 and $5)$.

At the seedling stage, maize plants could protect the surface soil from splash-erosion by preventing direct hitting of raindrops (Table 4) and reducing their kinetic energy (Table 1) and by changing the distribution of raindrops (Table 2) because of canopy gaps (Ghahramani et al., 2011; Miyata et al., 2009). Nevertheless, as discussed earlier, splash-erosion has a limited influence on total soil loss amount. Under $100 \mathrm{~mm} \mathrm{~h}^{-1}$, the amount of soil loss of $\mathrm{Vr}$ significantly dropped from 10.6 to $0.28 \mathrm{~kg}$ by $\mathrm{Vr}+\mathrm{Cm}$, while the runoff amount was non-significantly reduced from 703.25 to $620.90 \mathrm{~L}$, which indicated that the primary function of mulching is not reducing runoff volume. Thus, the excellent effects of mulching on erosion control shown in this experiment should mainly result in two other functions, reducing runoff strength and filtering out runoff soil particles (Prosdocimi et al., 2016a, b). Both functions caused a reduction in sediment concentration because of the effects of mulching as buffer strips (Fang, 2017).

\section{Horizontal ridge rupture}

Horizontal ridge rupture or breaching is a common concern in Northeast China, as erosive storms can occur in summer with short duration but high intensity; these storms often coincide with snowmelt runoff in spring (Li et al., 2016; Lu et al., 2016; Xu et al., 2018). Contour ridge stability is mainly related to ridge geometry, sloping land microtopography, soil physical properties of the ridge body, and rainfall characteristics (Liu et al., 2014a).

Generally, Hr can increase water infiltration before breaching (Liu et al., 2015; USDA-ARS, 2008, 2013) and lead to abundant sediment storage (Xu et al., 2018). The time of ridge rupture shortened with higher rainfall intensity as previous studies (Liu et al., 2015; Liu et al., 2014a; Liu et al., 2014b; Xu et al., 2018). The result of extremely high runoff and soil loss rates after rupture (Figure 4 and 5) was like the relationship between the peaks of runoff and sediment and ridge failure (Liu et al., 2015; Liu et al., 2014b; Xu et al., 2018). Averaged peak runoff and soil loss rates after ridge failure were 9.33- and 36.67-fold larger than their prior neighboring points, respectively (Figure 6 and 7). The ratio of peak sediment rate to base sediment rate under $\mathrm{Hr}$ in this study ranged from 13.84 to $94.70 \mathrm{~g} \mathrm{~L}^{-1}$. The varied range differed but included previous 
results reported by Liu et al. (2014b) and Xu et al. (2018). Our study showed that contour ridges ruptured at $50 \mathrm{~mm} \mathrm{~h}^{-1}$ were not in agreement with the results of Xu et al. (2018), possibly because of the differences in ridge geometry characteristics, such as ridge height. Liu et al. (2014b) suggested that increasing ridge height might be useful to prevent horizontal ridge failure and decrease soil loss hazard risk, according to enhanced water storage capacity.

Our study illustrated that mulching could not always avoid ridge rupture but can significantly postpone the collapse time of ridge failure (Figure 6 and 7), possibly because mulching improves soil properties (Kader et al., 2017; Kurothe et al., 2014; Prosdocimi et al., 2016a, b) and, therefore, alters runoff and soil erosion characteristics (Gholami et al., 2013).

\section{Conclusions}

Rainfall simulation experiments were conducted to study the effects of six measures of two tillage systems on water-based soil erosion of a black soil hillslope during the maize seedling stage under two rainfall intensities (50 and $100 \mathrm{~mm} \mathrm{~h}^{-1}$ ) in Northeast China. The results showed that corn seedlings can protect the surface soil from splash-erosion by reducing the kinetic energy and changing the distribution of raindrops. Conservation measures with mulching, including $\mathrm{Cm}, \mathrm{Hr}, \mathrm{Hr}+\mathrm{Cm}$, and $\mathrm{Vr}+\mathrm{Cm}$, significantly reduced water and soil loss compared to conventional tillage. Hr had a risk of ridge rupture, especially under heavy rainfall conditions; and rupturing of ridges provided an excessive sediment source and potentially triggered severe soil erosion. Mulching had an ideal erosion-controlling capacity. In addition, mulching can mitigate soil loss increase caused by heavy rainfall. The positive effects of mulching were based on its strong ability to reduce splasherosion and runoff volume and, more importantly, on its function to decrease runoff velocity and filter runoff sediment in. Vr further exacerbates soil erosion and should normally be avoided. $\mathrm{Hr}+\mathrm{Cm}$ showed the best performance in all cases and should be used as an optimized tillage measure on the black soil hillslope to restrict soil erosion at the corn seedling stage.

\section{Acknowledgements}

This work was supported by the National Key R \& D Program of China (No. 2016YFD0300301-03, 2017YFD0300608-2). Special thanks are owed to the anonymous reviewers and editors.

\section{Conflict of Interest Statement}

The authors declare no conflict of interest.

\section{References}

An, J., Zheng, F., Lu, J., \& Li, G. (2012). Investigating the role of raindrop impact on hydrodynamic mechanism of soil erosion under simulated rainfall conditions. Soil Science , 177 (8), 517-526. https://doi.org/10.1097/SS.0b013e3182639de1

Bailey, A., Deasy, C., Quinton, J., Silgram, M., Jackson, B., \& Stevens, C. (2013). Determining the cost of in-field mitigation options to reduce sediment and phosphorus loss. Land Use Policy ,30 (1), 234-242. https://doi.org/10.1016/j.landusepol.2012.03.027

Blanco-Moure, N., Moret-Fernandez, D., \& Lopez, M. V. (2012). Dynamics of aggregate destabilization by water in soils under long-term conservation tillage in semiarid Spain. Catena , 99 , 34-41. https://doi.org/10.1016/j.catena.2012.07.010

Bombino, G., Denisi, P., Gomez, J. A., \& Zema, D. A. (2019). Water infiltration and surface runoff in steep clayey soils of olive groves under different management practices. Water , 11 (2), 240. https://doi.org/10.3390/w11020240

Bombino, G., Denisi, P., Gomez, J. A., \& Zema, D. A. (2021). Mulching as best management practice to reduce surface runoff and erosion in steep clayey olive groves. International Soil and Water Conservation Research , 9 (1), 26-36. https://doi.org/10.1016/j.iswcr.2020.10.002 
Busari, M. A., Kukal, S. S., Kaur, A., Bhatt, R., \& Dulazi, A. A. (2015). Conservation tillage impacts on soil, crop and the environment.International Soil and Water Conservation Research , 3 (2), 119-129. https://doi.org/10.1016/j.iswcr.2015.05.002

Cerda, A., Gonzalez-Pelayo, O., Gimenez-Morera, A., Jordan, A., Pereira, P., Novara, A., Brevik, E. C., Prosdocimi, M., Mahmoodabadi, M., Keesstra, S., Orenes, F. G., \& Ritsema, C. J. (2016). Use of barley straw residues to avoid high erosion and runoff rates on persimmon plantations in Eastern Spain under low frequency-high magnitude simulated rainfall events. Soil Research , 54 (2), 154-165. https://doi.org/https://doi.org/10.1071/SR15092

Cerda, A., Rodrigo-Comino, J., Gimenez-Morera, A., \& Keesstra, S. D. (2017). An economic, perception and biophysical approach to the use of oat straw as mulch in Mediterranean rainfed agriculture land.Ecological Engineering , 108 , 162-171. https://doi.org/10.1016/j.ecoleng.2017.08.028

Chinese Ministry of Water Resources, Chinese Academy of Science, Chinese Academy of Engineering. (2010). Soil erosion control and ecological security in China: Northeast black soil region. Beijing: Science Press.

DeLonge, M., \& Stillerman, K. P. (2020).Eroding the Future: How Soil Loss Threatens Farming and Our Food Supply . Union of Concerned Scientists. https://www.ucsusa.org/resources/eroding-future

Derpsch, R., Franzluebbers, A. J., Duiker, S. W., Reicosky, D. C., Koeller, K., Friedrich, T., Sturny, W. G., Sa, J. C. M., \& Weiss, K. (2014). Why do we need to standardize no-tillage research? Soil \& Tillage Research , 137, 16-22. https://doi.org/10.1016/j.still.2013.10.002

Fang, H. Y. (2017). Impact of land use change and dam construction on soil erosion and sediment yield in the black soil region, Northeastern China. Land Degradation 83 Development , 28 (4), 1482-1492. https://doi.org/10.1002/ldr.2677

Garcia-Orenes, F., Roldan, A., Mataix-Solera, J., Cerda, A., Campoy, M., Arcenegui, V., \& Caravaca, F. (2012). Soil structural stability and erosion rates influenced by agricultural management practices in a semi-arid Mediterranean agro-ecosystem. Soil Use and Management ,28 (4), 571-579. https://doi.org/10.1111/j.1475-2743.2012.00451.x

Ghahramani, A., Ishikawa, Y., Gomi, T., Shiraki, K., \& Miyata, S. (2011). Effect of ground cover on splash and sheetwash erosion over a steep forested hillslope: A plot-scale study. Catena ,85 (1), 34-47. https://doi.org/10.1016/j.catena.2010.11.005

Gholami, L., Sadeghi, S. H., \& Homaee, M. (2013). Straw mulching effect on splash erosion, runoff, and sediment yield from eroded plots.Soil Science Society of America Journal , 77 (1), 268-278. https://doi.org/10.2136/sssaj2012.0271

Hansen, N. C., Allen, B. L., Baumhardt, R. L., \& Lyon, D. J. (2012). Research achievements and adoption of no-till, dryland cropping in the semi-arid U.S. Great Plains. Field Crops Research , 132 , 196-203. https://doi.org/https://doi.org/10.1016/j.fcr.2012.02.021

Hobbs, P. R., Sayre, K., \& Gupta, R. (2008). The role of conservation agriculture in sustainable agriculture. Philos Trans R Soc Lond B Biol Sci , 363 (1491), 543-555. https://doi.org/10.1098/rstb.2007.2169

Hu, W., Zheng, F. L., \& Bian, F. (2016). The directional components of splash erosion at different raindrop kinetic energy in the Chinese Mollisol Region. Soil Science Society of America Journal ,80 (5), 1329-1340. https://doi.org/10.2136/sssaj2016.03.0066

Huang, J., Wang, J., Zhao, X. N., Wu, P. T., Qi, Z. M., \& Li, H. B. (2014). Effects of permanent ground cover on soil moisture in jujube orchards under sloping ground: A simulation study. Agricultural Water Management , 138 , 68-77. https://doi.org/10.1016/j.agwat.2014.03.002

Hudson, N. (2015). Soil conservation: Fully revised and updated. New India Publishing Agency. 
Jordan, A., Zavala, L. M., \& Gil, J. (2010). Effects of mulching on soil physical properties and runoff under semi-arid conditions in southern Spain. Catena , 81 (1), 77-85. https://doi.org/10.1016/j.catena.2010.01.007

Kader, M. A., Senge, M., Mojid, M. A., \& Ito, K. (2017). Recent advances in mulching materials and methods for modifying soil environment. Soil \& Tillage Research , 168 , 155-166. https://doi.org/10.1016/j.still.2017.01.001

Keesstra, S. D. (2007). Impact of natural reforestation on floodplain sedimentation in the Dragonja basin, SW Slovenia. Earth Surface Processes and Landforms , 32 (1), 49-65. https://doi.org/10.1002/esp.1360

Keesstra, S., Pereira, P., Novara, A., Brevik, E. C., Azorin-Molina, C., Parras-Alcantara, L., Jordan, A., \& Cerda, A. (2016). Effects of soil management techniques on soil water erosion in apricot orchards.Science of the Total Environment , 551 , 357-366. https://doi.org/10.1016/j.scitotenv.2016.01.182

Kumar, S., Kadono, A., Lal, R., \& Dick, W. (2012). Long-term tillage and crop rotations for 47-49 years influences hydrological properties of two soils in Ohio. Soil Science Society of America Journal ,76 (6), 2195-2207. https://doi.org/10.2136/sssaj2012.0098

Kurothe, R. S., Kumar, G., Singh, R., Singh, H. B., Tiwari, S. P., Vishwakarma, A. K., Sena, D. R., \& Pande, V. C. (2014). Effect of tillage and cropping systems on runoff, soil loss and crop yields under semiarid rainfed agriculture in India. Soil \& Tillage Research ,140 , 126-134. https://doi.org/10.1016/j.still.2014.03.005

Lal, R. (2018). Sustainable intensification of China's agroecosystems by conservation agriculture. International Soil and Water Conservation Research , 6 (1), 1-12. https://doi.org/10.1016/j.iswcr.2017.11.001

Li, G. F., Zheng, F. L., Lu, J., Xu, X. M., Hu, W., \& Han, Y. (2016). Inflow rate impact on hillslope erosion processes and flow hydrodynamics. Soil Science Society of America Journal ,80 (3), 711-719. https://doi.org/10.2136/sssaj2016.02.0025

Liu, H. H., Zhang, T. Y., Liu, B. Y., Liu, G., \& Wilson, G. V. (2013). Effects of gully erosion and gully filling on soil depth and crop production in the black soil region, northeast China.Environmental Earth Sciences, 68 (6), 1723-1732. https://doi.org/10.1007/s12665-012-1863-0

Liu, Q. J., An, J., Wang, L. Z., Wu, Y. Z., \& Zhang, H. Y. (2015). Influence of ridge height, row grade, and field slope on soil erosion in contour ridging systems under seepage conditions. Soil \& Tillage Research , 147, 50-59. https://doi.org/10.1016/j.still.2014.11.008

Liu, Q. J., Shi, Z. H., Yu, X. X., \& Zhang, H. Y. (2014a). Influence of microtopography, ridge geometry and rainfall intensity on soil erosion induced by contouring failure. Soil and Tillage Research ,136 , 1-8. https://doi.org/https://doi.org/10.1016/j.still.2013.09.006

Liu, Q. J., Zhang, H. Y., An, J., \& Wu, Y. Z. (2014b). Soil erosion processes on row sideslopes within contour ridging systems.Catena , 115 , 11-18. https://doi.org/https://doi.org/10.1016/j.catena.2013.11.013

Liu, X. B., Zhang, S. L., Zhang, X. Y., Ding, G. W., \& Cruse, R. M. (2011). Soil erosion control practices in Northeast China: A mini-review. Soil \& Tillage Research , 117, 44-48. https://doi.org/10.1016/j.still.2011.08.005

Lu, J., Zheng, F. L., Li, G. F., Bian, F., \& An, J. (2016). The effects of raindrop impact and runoff detachment on hillslope soil erosion and soil aggregate loss in the Mollisol region of Northeast China.Soil $\mathscr{E}$ Tillage Research , 161 , 79-85. https://doi.org/10.1016/j.still.2016.04.002

Ma, B., Gale, W. J., Ma, F., Wu, F. Q., Li, Z. B., \& Wang, J. (2013). Transformation of rainfall by a soybean canopy. Transactions of the Asabe , 56 (6), 1285-1293. https://doi.org/10.13031/trans.56.9804

Mannering, J. V., \& Meyer, L. D. (1963). The effects of various rates of surface mulch on infiltration and erosion. Soil Science Society of America Journal , 27 (1), 84-86. https://doi.org/10.2136/sssaj1963.03615995002700010029x 
Miyata, S., Kosugi, K., Gomi, T., \& Mizuyama, T. (2009). Effects of forest floor coverage on overland flow and soil erosion on hillslopes in Japanese cypress plantation forests. Water Resources Research , 42 , W06402. https://doi.org/10.1029/2008wr007270

Montgomery, D. R. (2007). Soil erosion and agricultural sustainability.Proceedings of the National Academy of Sciences of the United States of America , 104 (33), 13268-13272. https://doi.org/10.1073/pnas.0611508104

Montgomery, D. R. (2017). Growing a revolution: Bring our soil back to life. W. W. Norton \& Company.

Morgan, R. P. C. (1978). Field studies of rainsplash erosion.Earth Surface Processes , 3 (3), 295-299. https://doi.org/https://doi.org/10.1002/esp.3290030308

Mulumba, L. N., \& Lal, R. (2008). Mulching effects on selected soil physical properties. Soil \& Tillage Research , 98 (1), 106-111. https://doi.org/10.1016/j.still.2007.10.011

Nearing, M. A., Norton, L. D., Bulgakov, D. A., Larionov, G. A., West, L. T., \& Dontsova, K. M. (1997). Hydraulics and erosion in eroding rills. Water Resources Research , 33 (4), 865-876. https://doi.org/10.1029/97wr00013

Ouimet, W. B., Whipple, K. X., \& Granger, D. E. (2009). Beyond threshold hillslopes: Channel adjustment to base-level fall in tectonically active mountain ranges. Geology , 37 (7), 579-582. https://doi.org/10.1130/G30013a.1

Palm, C., Blanco-Canqui, H., DeClerck, F., Gatere, L., \& Grace, P. (2014). Conservation agriculture and ecosystem services: An overview.Agriculture Ecosystems \& Environment , 187 , 87-105. https://doi.org/10.1016/j.agee.2013.10.010

Poesen, J. W. A., \& Lavee, H. (1991). Effects of size and incorporation of synthetic mulch on runoff and sediment yield from interrils in a laboratory study with simulated rainfall. Soil and Tillage Research, 21 (3), 209-223. https://doi.org/https://doi.org/10.1016/0167-1987(91)90021-O

Polyakov, V. O., \& Lal, R. (2008). Soil organic matter and $\mathrm{CO}_{2}$ emission as affected by water erosion on field runoff plots. Geoderma , 143 (1-2), 216-222. https://doi.org/10.1016/j.geoderma.2007.11.005

Polyakov, V. O., \& Nearing, M. A. (2003). Sediment transport in rill flow under deposition and detachment conditions. Catena ,51 (1), 33-43. https://doi.org/Pii S0341-8162(02)00090-5

Prosdocimi, M., Jordan, A., Tarolli, P., Keesstra, S., Novara, A., \& Cerda, A. (2016a). The immediate effectiveness of barley straw mulch in reducing soil erodibility and surface runoff generation in Mediterranean vineyards. Science of the Total Environment , 547 , 323-330. https://doi.org/10.1016/j.scitotenv.2015.12.076

Prosdocimi, M., Tarolli, P., \& Cerda, A. (2016b). Mulching practices for reducing soil water erosion: A review. Earth-Science Reviews ,161 , 191-203. https://doi.org/10.1016/j.earscirev.2016.08.006

Rodriguez-Caballero, E., Canton, Y., Chamizo, S., Afana, A., \& Sole-Benet, A. (2012). Effects of biological soil crusts on surface roughness and implications for runoff and erosion. Geomorphology ,145-146 , 81-89. https://doi.org/https://doi.org/10.1016/j.geomorph.2011.12.042

Romkens, M. J. M., Helming, K., \& Prasad, S. N. (2002). Soil erosion under different rainfall intensities, surface roughness, and soil water regimes. Catena , 46 (2), 103-123. https://doi.org/https://doi.org/10.1016/S0341-8162(01)00161-8

Sartori, M., Philippidis, G., Ferrari, E., Borrelli, P., Lugato, E., Montanarella, L., \& Panagos, P. (2019). A linkage between the biophysical and the economic: Assessing the global market impacts of soil erosion. Land Use Policy , 86 , 299-312. https://doi.org/https://doi.org/10.1016/j.landusepol.2019.05.014

Sharratt, B., Wendling, L., \& Feng, G. (2012). Surface characteristics of a windblown soil altered by tillage intensity during summer fallow.Aeolian Research , 5 , 1-7. 
https://doi.org/https://doi.org/10.1016/j.aeolia.2012.02.002

Shen, C. P., Gong, Z. P., \& Wen, J. T. (2005). Comparison study on soil and water loss of cross ridge and longitudinal ridge. Bulletin of Soil and Water Conservation 25 (4), 48-49. https://doi.org/10.3969/j.issn.1000288X.2005.04.012

Shen, H. O., Zheng, F. L., Wen, L. L., Han, Y., \& Hu, W. (2016). Impacts of rainfall intensity and slope gradient on rill erosion processes at loessial hillslope. Soil \& Tillage Research ,155 , 429-436. https://doi.org/10.1016/j.still.2015.09.011

Song, Y., \& Zhang, Z. X. (2011). The effect of different tillage measures on soil erosion in sloe farm-land in black soil region.Research of Soil and Water Conservation , 18 (2), 14-16, 25. https://doi.org/CNKI:SUN:STBY.0.2011-02-004

Sun, L., An, G., Ding, L., \& Shen, B. (2000). A climatic analysis of summer precipitation features and anomaly in Northeast China. Acta Meteorologica Sinica 58 (1), 70-82. https://doi.org/10.11676/qxxb2000.007

Tang, K. L. (2004). Soil and water conservation in China . Science Press.

Thaler, E. A., Larsen, I. J., \& Yu, Q. (2021). The extent of soil loss across the US Corn Belt. Proceedings of the National Academy of Sciences of the United States of America , 118 (8). https://doi.org/10.1073/pnas.1922375118

Tran, D. Q., \& Kurkalova, L. A. (2019). Persistence in tillage decisions: Aggregate data analysis. International Soil and Water Conservation Research , 7 (2), 109-118. https://doi.org/10.1016/j.iswcr.2019.03.002

USDA-ARS. (2008). User's reference guide, Revised Universal Soil Loss Equation Version 2http://www.ars.usda.gov/sp2UserFiles/Place/64080510/RUSLE/RUSLE2_User_Ref_ Guide.pdf.

USDA-ARS. (2013). Science documentation, Revised Universal Soil Loss Equation Version 2https://www.ars.usda.gov/ARSUserFiles/60600505/RUSLE/RUSLE2_Science_Doc.pdf

Van den Putte, A., Govers, G., Diels, J., Langhans, C., Clymans, W., Vanuytrecht, E., Merckx, R., \& Raes, D. (2012). Soil functioning and conservation tillage in the Belgian Loam Belt. Soil \& 8 Tillage Research , 122 , 1-11. https://doi.org/10.1016/j.still.2012.02.001

Vermang, J., Norton, L. D., Huang, C., Cornelis, W. M., da Silva, A. M., \& Gabriels, D. (2015). Characterization of soil surface roughness effects on runoff and soil erosion rates under simulated rainfall.Soil Science Society of America Journal , 79 (3), 903-916. https://doi.org/10.2136/sssaj2014.08.0329

Wang, L. H., Wang, Y. F., Saskia, K., Artemi, C., Ma, B., \& Wu, F. Q. (2018). Effect of soil management on soil erosion on sloping farmland during crop growth stages under a large-scale rainfall simulation experiment. Journal of Arid Land , 10 (6), 921-931. https://doi.org/10.1007/s40333-018-0016-z

Wang, W., Deng, R., \& Zhang, S. (2012). Spatial pattern change and topographic differentia of gully erosion in the type black soil area of Northeast China during the past 40 years. Geography and Geo-Information Science , 28 (3), 68-71. https://doi.org/CNKI:SUN:DLGT.0.2012-03-018

Wang, Y. (1993). Experimental Study of soil erosion by overland runoff in the rolling gullied Loess Region. Soil and Water Conservation in China , 5 , 25-28. https://doi.org/CNKI:SUN:ZGSB.0.1993-07-007

Woolhiser, D. A., \& Goodrich, D. C. (1988). Effect of storm rainfall intensity patterns on surface runoff. Journal of Hydrology ,102 (1), 335-354. https://doi.org/10.1016/0022-1694(88)90106-0

$\mathrm{Xu}$, P., Wang, Y., \& Fu, B. (2008). Experimental research on the influence of two cultivation practices on rainfall runoff and (sandy and muddy) sediment generating processes in purple soil environment. Chinese Journal of Geochemistry 27 (4), 370-376. https://doi.org/CNKI:SUN:DQHB.0.2008-04-007 
Xu, X. M., Zheng, F. L., Qin, C., Wu, H. Y., \& Wilson, G. V. (2017). Impact of cornstalk buffer strip on hillslope soil erosion and its hydrodynamic understanding. Catena , 149 , 417-425. https://doi.org/10.1016/j.catena.2016.10.016

Xu, X. M., Zheng, F. L., Wilson, G. V., He, C., Lu, J., \& Bian, F. (2018). Comparison of runoff and soil loss in different tillage systems in the Mollisol region of Northeast China. Soil \& Tillage Research, 177 , 1-11. https://doi.org/10.1016/j.still.2017.10.005

Xu, X. Z., Xu, Y., Chen, S. C., Xu, S. G., \& Zhang, H. W. (2010). Soil loss and conservation in the black soil region of Northeast China: a retrospective study. Environmental Science 83 Policy ,13 (8), 793-800. https://doi.org/10.1016/j.envsci.2010.07.004

Yang, W. G., Han, Y., Zheng, F. L., Wang, Z. L., Yi, Y., \& Feng, Z. Z. (2016). Investigating spatial distribution of soil quality index and its impacts on corn yield in a cultivated catchment of the Chinese Mollisol Region. Soil Science Society of America Journal , 80 (2), 317-327. https://doi.org/10.2136/sssaj2015.09.0335

You, N. S., Dong, J. W., Huang, J. X., Du, G. M., Zhang, G. L., He, Y. L., Yang, T., Di, Y. Y., \& Xiao, X. M. (2021). The 10-m crop type maps in Northeast China during 2017-2019. Scientific Data,8 (1). https://doi.org/10.1038/s41597-021-00827-9

Zhang, S. X., Li, Q., Zhang, X. P., Wei, K., Chen, L. J., \& Liang, W. J. (2012). Effects of conservation tillage on soil aggregation and aggregate binding agents in black soil of Northeast China. Soil \&5 Tillage Research , 124 , 196-202. https://doi.org/10.1016/j.still.2012.06.007

Zhang, X. K., Xu, J. H., Lu, X. Q., Deng, Y. J., \& Gao, D. W. (1992). A study on the soil loss equation in Hei-longjiang Province.Bulletin of Soil Water Conservation , 12 (4), 1-9. https://doi.org/CNKI:SUN:STTB.0.1992-04-000

Zhang, Y. B., Cao, N., Su, X. G., Xu, X. H., Yan, F., \& Yang, Z. M. (2009). Effects of soil and water conservation on soil properties in the Low Mountain and Hill Area of Jilin province. Bulletin of Soil and Water Conservation, 29 (5), 224-229. https://doi.org/CNKI:SUN:STT.0.2009-05-053

Zhang, Y. B., Zheng, F. L., \& Wu, M. (2007). Research progresses in agricultural non-point source pollution caused by soil erosion.Advances in Water Science , 18 (1), 123-132. https://doi.org/10.3321/j.issn:10016791.2007 .01 .021

Zhang, Y. F., Wang, X. P., Hu, R., Pan, Y. X., \& Paradeloc, M. (2015). Rainfall partitioning into throughfall, stemflow and interception loss by two xerophytic shrubs within a rain-fed re-vegetated desert ecosystem, northwestern China. Journal of Hydrology , 527 , 1084-1095. https://doi.org/10.1016/j.jhydrol.2015.05.060

Zhang, Y. G., Nearing, M. A., Zhang, X. C., Xie, Y., \& Wei, H. (2010). Projected rainfall erosivity changes under climate change from multimodel and multiscenario projections in Northeast China. Journal of Hydrology , 384 (1-2), 97-106. https://doi.org/10.1016/j.jhydrol.2010.01.013

Zhao, J. F., Guo, J. P., Xu, Y. L., \& Mu, J. (2015). Effects of climate change on cultivation patterns of spring maize and its climatic suitability in Northeast China. Agriculture Ecosystems 83 Environment, 202 , 178-187. https://doi.org/10.1016/j.agee.2015.01.013

Zhao, S. (1986). Physical geography of China . Beijing: Science Press and John Wiley.

\section{Figure Legends}

Figure 1. Field scenario at the maize seedling stage in the Mollisols of Northeast China.

Figure 2 . Experimental plots, status, and rainfall setup.

Figure 3 . Rainfall intensity calibration and small splash-cup positions. (a) Rainfall intensity calibration performed every time before rainfall experiment. (b) Positions for small splash-cups in plots with vertical ridges. (c) Positions for small splash-cups in plots with horizontal ridges. 
Figure 4. Runoff amount under different tillage measures. Control (CK), flat-planting without ridges and mulching; Hr, horizontal ridging without mulching; Vr, vertical ridging without mulching; Cm, flatplanting and mulching without ridges; $\mathrm{Hr}+\mathrm{Cm}$, horizontal ridging with mulching; $\mathrm{Vr}+\mathrm{Cm}$, vertical ridging with mulching. The vertical error bars indicate LSD at $P<0.05$. Note: The asterisk $\left(^{*}\right)$ indicates ridge rupture.

Figure 5 . Soil loss amount under different tillage measures. Control (CK), flat-planting without ridges and mulching; Hr, horizontal ridging without mulching; Vr, vertical ridging without mulching; Cm, cornstalk mulching; $\mathrm{Hr}+\mathrm{Cm}$, horizontal ridging with mulching; $\mathrm{Vr}+\mathrm{Cm}$, vertical ridging with mulching. The vertical error bars indicate LSD at $P<0.05$. Note: The asterisk $\left(^{*}\right)$ indicates ridge rupture.

Figure 6 . Runoff rate under different tillage measures. Control (CK), flat-planting without ridges and mulching; Hr, horizontal ridging without mulching; Vr, vertical ridging without mulching; $\mathrm{Cm}$, cornstalk mulching; $\mathrm{Hr}+\mathrm{Cm}$, horizontal ridging with mulching; $\mathrm{Vr}+\mathrm{Cm}$, vertical ridging with mulching.

Figure 7 . Soil loss rate under different tillage measures. Control (CK), flat-planting without ridges and mulching; Hr, horizontal ridging without mulching; Vr, vertical ridging without mulching; $\mathrm{Cm}$, cornstalk mulching; $\mathrm{Hr}+\mathrm{Cm}$, horizontal ridging with mulching; $\mathrm{Vr}+\mathrm{Cm}$, vertical ridging with mulching.

Figure 8 . Correlation between soil loss and influencing factors (a), correlation of soil loss amount and soil splash-detachment; (b), correlation of soil loss amount and splash-transport amount; (c), correlation of soil loss amount and runoff loss amount; d. correlation of soil loss amount and runoff velocity. Note: Correlations between total soil loss amount and four inferred influencing factors; The symbolindicatesridgeruptureduringtherainfallexperiment.

Table 1. Effect of canopy on kinetic energy

\begin{tabular}{llll}
\hline & $50 \mathrm{~mm} \mathrm{~h}^{-1}$ & $50 \mathrm{~mm} \mathrm{~h}^{-1}$ & $100 \mathrm{~mm} \mathrm{~h}^{-1}$ \\
\hline & $\mathrm{CM}$ & $\mathrm{CT}$ & $\mathrm{CM}$ \\
kinetic energy, $\mathrm{J} /\left(\mathrm{m}^{2}[?] \mathrm{mm}\right)$ & kinetic energy, $\mathrm{J} /\left(\mathrm{m}^{2}[?] \mathrm{mm}\right)$ & kinetic energy, $\mathrm{J} /\left(\mathrm{m}^{2}[?] \mathrm{mm}\right)$ & kinetic energy, \\
above & $16.43 \mathrm{c}$ & $16.43 \mathrm{c}$ & $18.19 \mathrm{a}$ \\
below & $15.78 \mathrm{~d}$ & $15.84 \mathrm{~d}$ & $17.25 \mathrm{~b}$ \\
total kinetic energy, $\mathrm{J} / \mathrm{m}^{2}$ & total kinetic energy, $\mathrm{J} / \mathrm{m}^{2}$ & total kinetic energy, $\mathrm{J} / \mathrm{m}^{2}$ & total kinetic en \\
above & $196.5 \mathrm{~d}$ & $196.5 \mathrm{~d}$ & $407.64 \mathrm{a}$ \\
below & $174.05 \mathrm{e}$ & $178.2 \mathrm{e}$ & $357.97 \mathrm{c}$ \\
\hline
\end{tabular}

$\mathrm{CM}$, conservation tillage measures, including $\mathrm{Cm}$, cornstalk mulching without ridges; $\mathrm{Hr}$, horizontal ridging without mulching; $\mathrm{Vr}+\mathrm{Cm}$, vertical ridging with mulching; $\mathrm{Hr}+\mathrm{Cm}$, horizontal ridging with mulching. CT, conventional tillage practices, including control (CK), flat-planting without ridges and mulching, and $\mathrm{Vr}$, vertical ridging without mulching.

Values followed by different letters are significantly different at $P<0.05$ according to the LSD test.

Table 2

Effect of canopy on raindrop diameter

\begin{tabular}{lllll}
\hline Raindrop diameter, $\mathrm{mm}$ & $50 \mathrm{~mm} \mathrm{~h}^{-1}, \%$ & $50 \mathrm{~mm} \mathrm{~h}^{-1}, \%$ & $100 \mathrm{~mm} \mathrm{~h}^{-1}, \%$ & $100 \mathrm{~mm} \mathrm{~h}^{-1}, \%$ \\
\hline & above & below & above & Below \\
$0.5-1$ & 3.16 & 2.08 & 5.02 & 3.01 \\
$1-1.5$ & 32.81 & 29.87 & 35.97 & 34.99 \\
$1.5-2.0$ & 19.96 & 17.96 & 22.99 & 21.00 \\
$2.0-2.5$ & 20.95 & 19.95 & 17.00 & 21.99
\end{tabular}




\begin{tabular}{lllll}
\hline Raindrop diameter, $\mathrm{mm}$ & $50 \mathrm{~mm} \mathrm{~h}^{-1}, \%$ & $50 \mathrm{~mm} \mathrm{~h}^{-1}, \%$ & $100 \mathrm{~mm} \mathrm{~h}^{-1}, \%$ & $100 \mathrm{~mm} \mathrm{~h}^{-1}, \%$ \\
\hline $2.5-3$ & 12.06 & 13.99 & 10.01 & 13.00 \\
$3-3.5$ & 11.07 & 13.00 & 9.01 & 5.01 \\
$3.5-4$ & 0 & 2.08 & 0 & 1.01 \\
$4-4.5$ & 0 & 1.08 & 0 & 0 \\
\hline
\end{tabular}

Table 3

Runoff-yielding time and runoff velocity under different tillage practices.

\begin{tabular}{lllll}
\hline Treatment & Runoff-yielding time $(\mathrm{s})$ & Runoff-yielding time $(\mathrm{s})$ & Runoff velocity $\left(10^{-2} \mathrm{~m} \mathrm{~s}^{-1}\right)$ & Runoff veloc \\
\hline & $50 \mathrm{~mm} \mathrm{~h}^{-1}$ & $100 \mathrm{~mm} \mathrm{~h}^{-1}$ & $50 \mathrm{~mm} \mathrm{~h}^{-1}$ & $100 \mathrm{~mm} \mathrm{~h}^{-1}$ \\
$\mathrm{CK}$ & $129 \mathrm{~d}$ & $69 \mathrm{e}$ & $5.83 \mathrm{~b}$ & $17.95 \mathrm{a}$ \\
$\mathrm{Cm}$ & $611 \mathrm{~b}$ & $260 \mathrm{c}$ & $1.41 \mathrm{c}$ & $3.07 \mathrm{c}$ \\
$\mathrm{Vr}$ & $132 \mathrm{~d}$ & $71 \mathrm{e}$ & $8.76 \mathrm{a}$ & $19.77 \mathrm{a}$ \\
$\mathrm{Hr}$ & $1700 \mathrm{a}$ & $1332 \mathrm{~b}$ & $0.96 \mathrm{~d}$ & $5.12 \mathrm{~b}$ \\
$\mathrm{Vr}+\mathrm{Cm}$ & $374 \mathrm{c}$ & $154 \mathrm{~d}$ & $1.64 \mathrm{c}$ & $4.01 \mathrm{~b}$ \\
$\mathrm{Hr}+\mathrm{Cm}$ & $\mathrm{NA}$ & $1634 \mathrm{a}$ & $\mathrm{NA}$ & $0.65 \mathrm{~d}$ \\
\hline
\end{tabular}

CK, control, flat-planting without ridges and mulching; $\mathrm{Cm}$, cornstalk mulching without ridges; $\mathrm{Vr}$, ridging without mulching; $\mathrm{Hr}$, horizontal ridging without mulching; $\mathrm{Vr}+\mathrm{Cm}$, vertical ridging with mulching; $\mathrm{Hr}+\mathrm{Cm}$, horizontal ridging with mulching; $\mathrm{NA}, \mathrm{Hr}+\mathrm{Cm}$-treated plots prevented runoff throughout the rainfall experiment.

Values in the same column followed by different letters are significantly different at $P<0.05$ according to the LSD test.

Table 4

Splash-detachment and splash-transport under different tillage practices.

\begin{tabular}{lllll}
\hline Treatment & Treatment & $50 \mathrm{~mm} \mathrm{~h}^{-1}$ & $50 \mathrm{~mm} \mathrm{~h}^{-1}$ & $50 \mathrm{~mm} \mathrm{~h}^{-1}$ \\
\hline & & Splash-detachment, $\mathrm{g} / \mathrm{m}^{2}$ & Splash-transport, $\mathrm{g} / \mathrm{m}^{2}$ & Ratio of transport, \\
Conventional tillage & $\mathrm{CK}$ & 377.55 & 40.39 & 10.70 \\
& $\mathrm{Vr}$ & 386.13 & 36.69 & 9.50 \\
Conservation tillage & $\mathrm{Cm}$ & 7.97 & 0.67 & 8.35 \\
& $\mathrm{Hr}$ & 369.24 & 43.18 & 11.69 \\
& $\mathrm{Vr}+\mathrm{Cm}$ & 6.16 & 0.76 & 12.31 \\
& $\mathrm{Hr}+\mathrm{Cm}$ & 7.92 & 0.81 & 10.23 \\
\hline
\end{tabular}

CK, control, flat-planting without ridges and mulching; $\mathrm{Cm}$, cornstalk mulching without ridges; $\mathrm{Vr}$, ridging without mulching; $\mathrm{Hr}$, horizontal ridging without mulching; $\mathrm{Vr}+\mathrm{Cm}$, vertical ridging with mulching; $\mathrm{Hr}+\mathrm{Cm}$, horizontal ridging with mulching.

Table 5

Change in soil water content on soil profile pre- and post-rainfall and infiltration under different tillage practices 


\begin{tabular}{|c|c|c|c|c|c|}
\hline Treatments & Treatments & Depth, cm & $50 \mathrm{~mm} \mathrm{~h}^{-1}$ & $50 \mathrm{~mm} \mathrm{~h}^{-1}$ & $50 \mathrm{~mm} \mathrm{~h}^{-1}$ \\
\hline & & & $\begin{array}{l}\text { Soil water content, \% } \\
\text { Pre- rainfall }\end{array}$ & $\begin{array}{l}\text { Soil water content, \% } \\
\text { Post- rainfall }\end{array}$ & $\begin{array}{l}\text { Soil water } \\
\text { Rising rat }\end{array}$ \\
\hline \multirow[t]{6}{*}{ Conventional tillage } & CK & $0-5$ & 21.22 & 25.04 & 17.99 \\
\hline & & $5-10$ & 26.59 & 28.19 & 5.99 \\
\hline & & $10-20$ & 22.15 & 22.33 & 0.81 \\
\hline & $\mathbf{V r}$ & $0-5$ & 24.25 & 27.69 & 14.18 \\
\hline & & $5-10$ & 24.10 & 25.63 & 6.37 \\
\hline & & $10-20$ & 22.88 & 23.18 & 1.32 \\
\hline \multirow[t]{12}{*}{ Conservation tillage } & $\mathrm{Cm}$ & $0-5$ & 27.19 & 29.31 & 7.80 \\
\hline & & $5-10$ & 31.00 & 33.33 & 7.50 \\
\hline & & $10-20$ & 27.19 & 29.07 & 6.90 \\
\hline & $\mathrm{Hr}$ & $0-5$ & 27.56 & 35.67 & 29.42 \\
\hline & & $5-10$ & 27.62 & 32.12 & 16.30 \\
\hline & & $10-20$ & 25.22 & 27.65 & 9.64 \\
\hline & $\mathrm{Vr}+\mathrm{Cm}$ & $0-5$ & 28.54 & 32.65 & 14.39 \\
\hline & & $5-10$ & 31.39 & 34.69 & 10.51 \\
\hline & & $10-20$ & 23.45 & 25.94 & 10.62 \\
\hline & $\mathrm{Hr}+\mathrm{Cm}$ & $0-5$ & 27.70 & 35.28 & 27.38 \\
\hline & & $5-10$ & 30.11 & 34.18 & 13.52 \\
\hline & & $10-20$ & 25.34 & 29.81 & 17.64 \\
\hline
\end{tabular}

CK, control, planted flat without ridges and mulching; Cm, cornstalk mulching; Vr, vertical ridges without mulching; $\mathrm{Hr}$, horizontal ridges without mulching; $\mathrm{Vr}+\mathrm{Cm}$, vertical ridges with mulching; $\mathrm{Hr}+\mathrm{Cm}$, horizontal ridges with mulching.

Hosted file

graph abstract.ppt available at https://authorea.com/users/415156/articles/523053horizontal-ridging-with-mulching-as-the-best-tillage-practice-to-reduce-surface-runoffand-erosion-in-a-mollisol-hillslope-at-the-maize-seedling-stage 


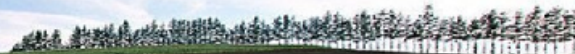
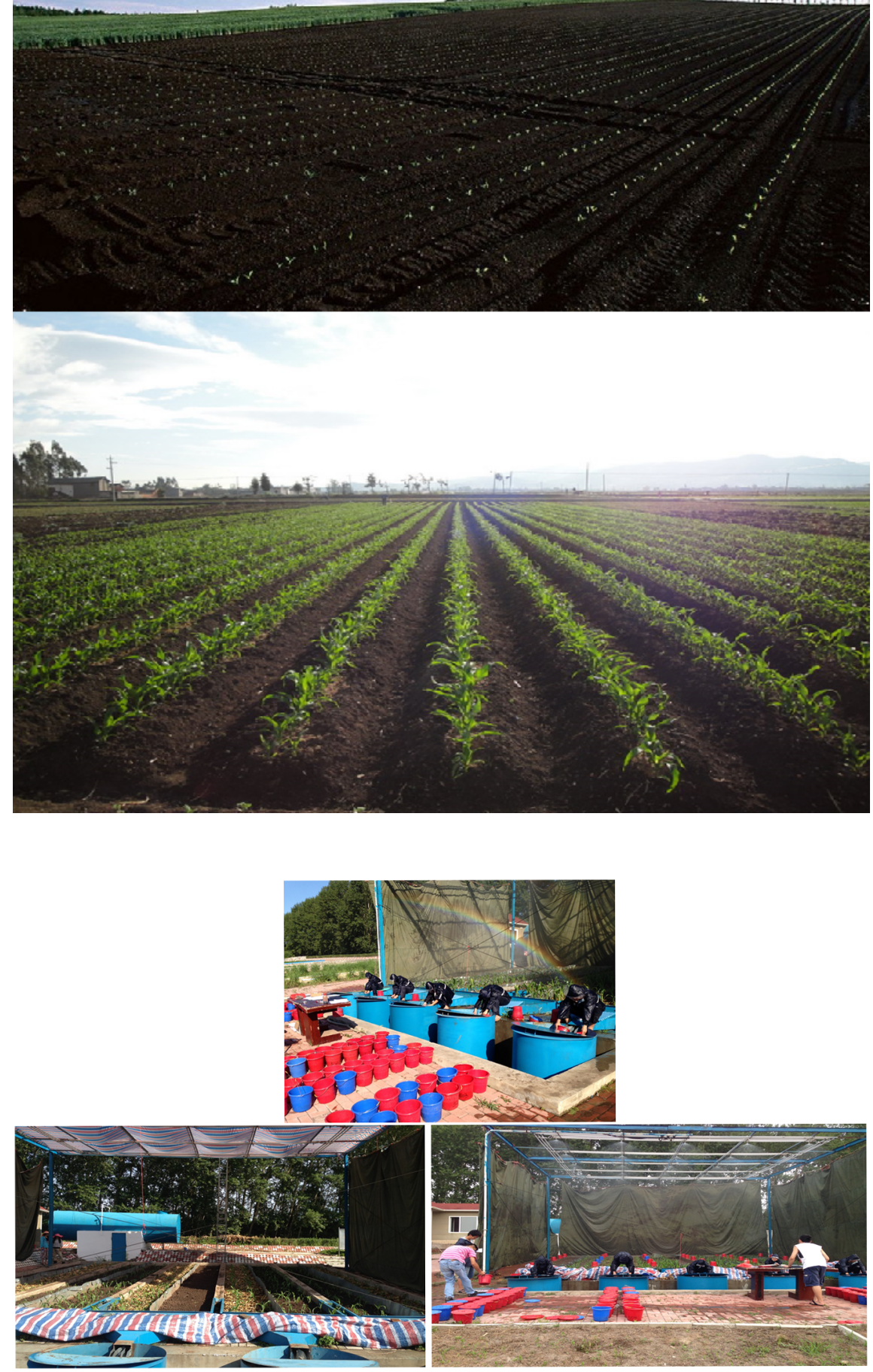

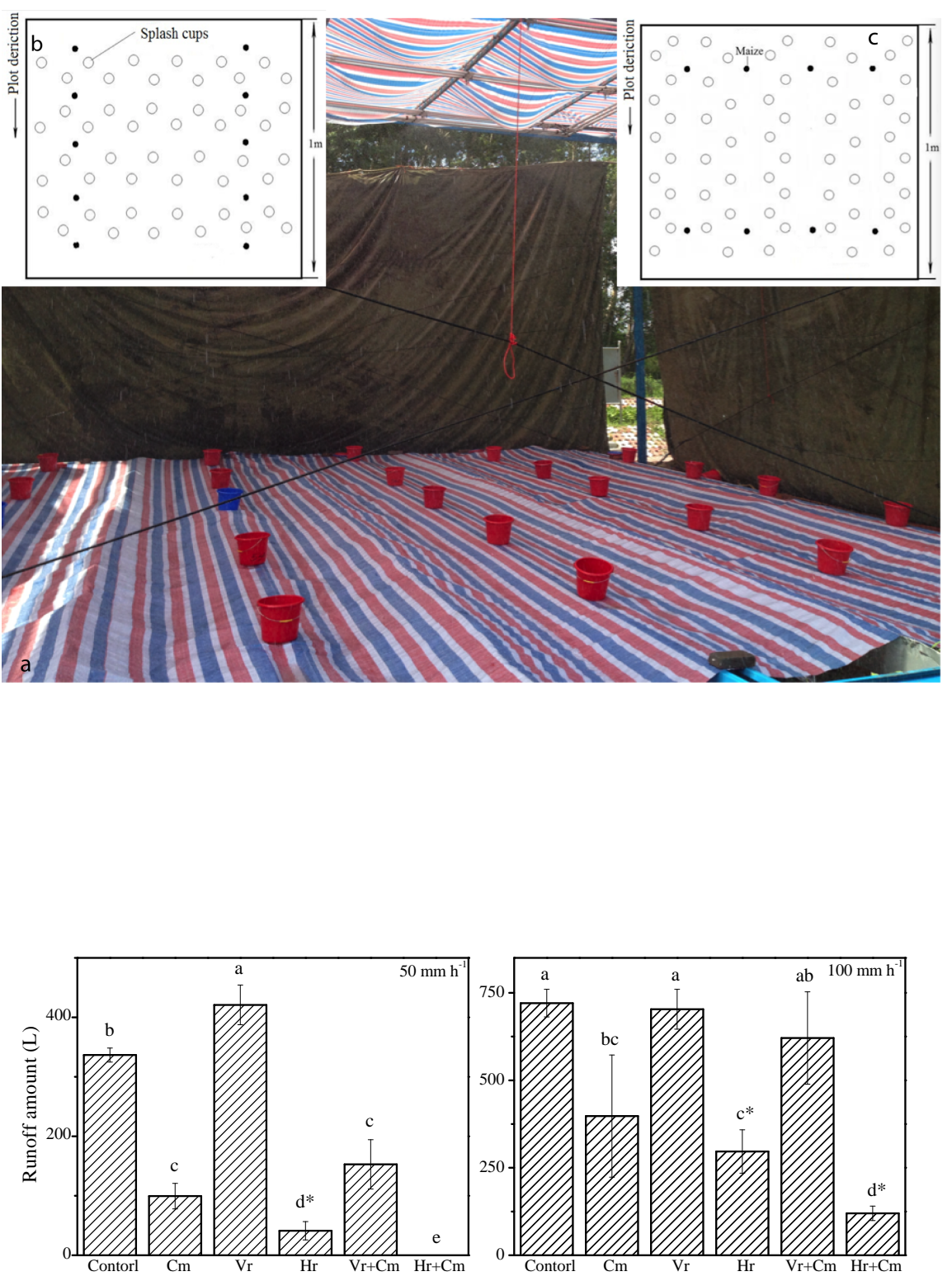

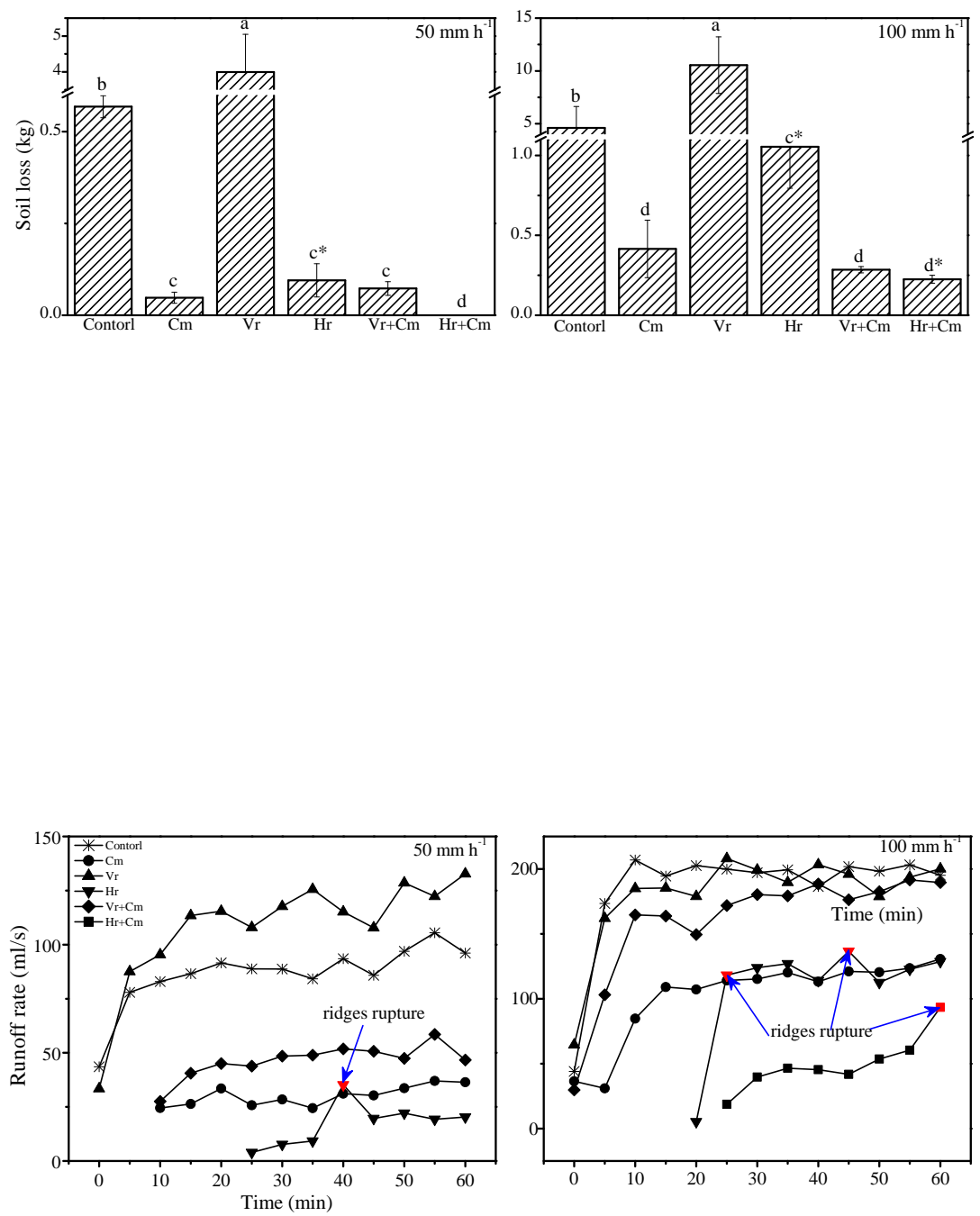

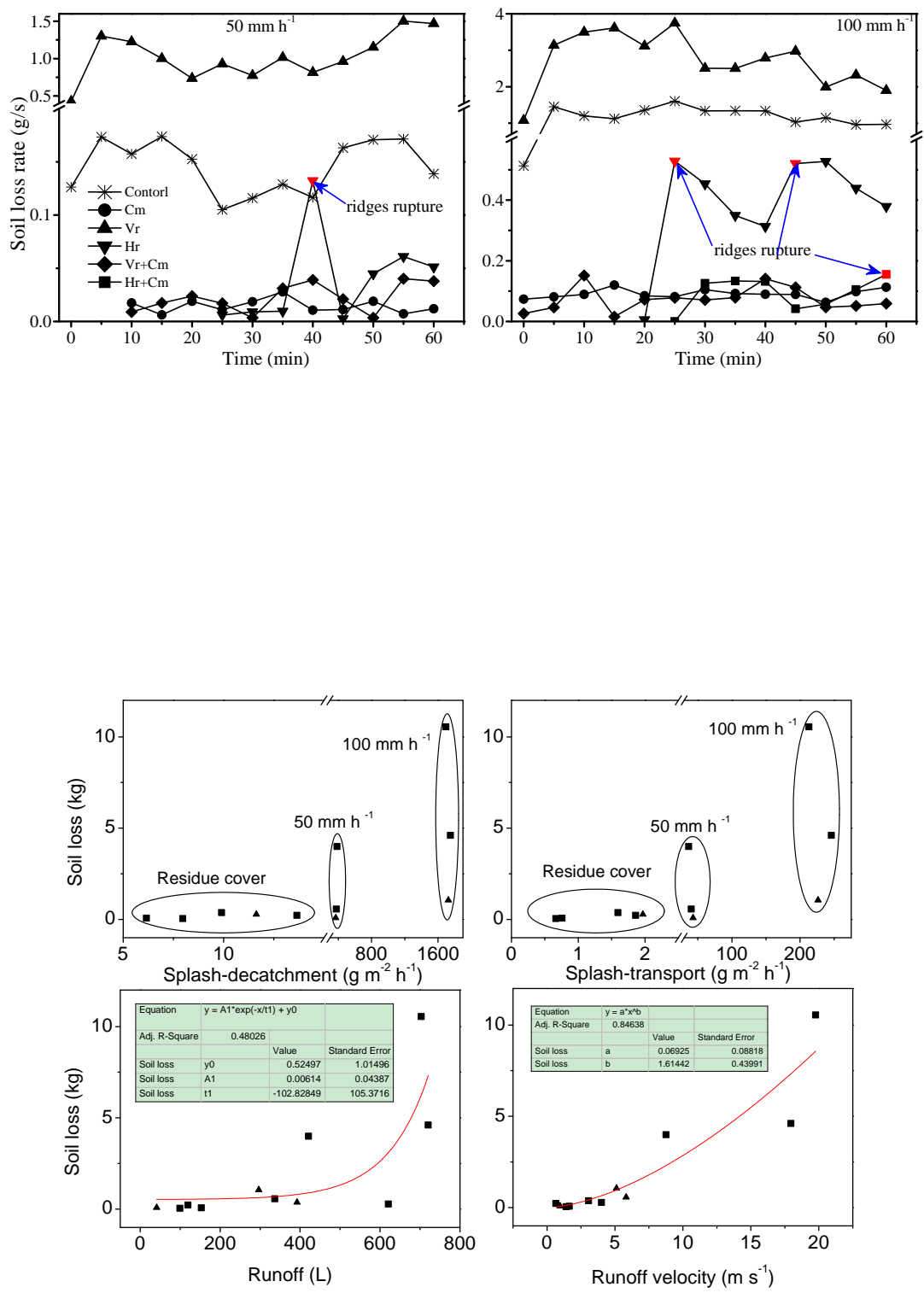